\title{
VERSAILLES, VIENNA AND BEYOND: CHANGING VIEWS OF HOUSEHOLD AND GOVERNMENT IN EARLY MODERN EUROPE
}

\author{
Jeroen Duindam
}

\section{Introduction}

The palace of Versailles encapsulates the image of the European court in the early modern age. The imposing architecture of the palace buildings and gardens, amplifying the monarch in the symbolic heart of his realm, tells a story repeated and embellished since the times of the Sun King. Royal power, restored after the Fronde rebellion (1648-1653), prevailed over unruly nobles for good. Court and palace had served as the king's instruments in the process. Bringing together the nobles of the realm in Versailles, Louis XIV (1638-1715) managed to 'domesticate' these erstwhile indomitable characters. Financial problems had propelled them towards the palace, where they enjoyed the king's benefits. Once at court, the grandees gradually lost their connections in the regions. Conspicuous consumption made them ever more dependent on royal graces. The ongoing battle for prestige among the nobles in the centre allowed the king to rule by fomenting strife among his former rivals. Occupying and balancing the nobles through the niceties of ceremony and politesse, the king in the meantime renovated and modernized the state apparatus in tandem with his bourgeois administrators. The court catered for the nobles and nominally upheld their position, yet at the same time it imprisoned them in a web of vanities and eroded their regional power bases.

This persuasive image, implicitly present in French literature since the later eighteenth century, was most systematically and powerfully worded by Norbert Elias. ${ }^{1}$ His sociological study relied strongly on

\footnotetext{
${ }^{1}$ Norbert Elias, Die höfische Gesellschaft. Untersuchungen zur Soziologie des Königtums und der höfischen Aristokratie. Mit einer Einleitung: Soziologie und Geschichtswissenschaft (Darmstadt; Neuwied 1969); idem, Über den Prozeß der Zivilisation. Soziogenetische und Psychogenetische Untersuchungen. I: Wandlungen des Verhaltens in den Weltlichen Oberschichten des Abendlandes. II: Wandlungen der Gesellschaft. Entwurf zu einer Theorie der Zivilisation (Bern 1969).
} 
the memoirs of the duke of Saint-Simon, son of one of Louis XIII's favourites whose hopes of favour and high office at Louis XIV's court had been disappointed bitterly. Elias took over his main witness' carefully constructed view of the Sun King as nemesis of the French nobility. Their version of Versailles became shorthand for a coherent definition and explanation of court life all over Europe, stressing the centrality of the king in his palace, and depicting the court as a predominantly noble environment secluded from the apparatus of the state. We see a punctilious salon writ large, rather than a centre of power and decision-making; we encounter nobles as participants in an ongoing battle for préséance rather than as councilors, governors and soldiers. The isolation of the nobles in the vacuum of court life offered an explanation for the expansion of courts in early modern Europe, and their increasingly rigid ceremonial: this was a luxurious prison, a gilded cage. The political rationale of the court, then, had been to separate pouvoir from grandeur, ministers from nobles, state from household. ${ }^{2}$ The expanding and ceremonializing households had offered a convenient solution for the main obstacle hindering state building: entrenched noble regional elites.

The view of the court as a gilded cage matched a phase in European historiography showing a strong predilection for institutions and offices seen as leading towards the modern state: bureaucracies, councils, ministers, parliaments. The domestic context of dynastic rulership was seen as trivial and unworthy of study. Research concentrated on the political institutions that were to become the heart of the state in the nineteenth and twentieth centuries-when indeed the domestic establishments serving royalty were receding into political insignificance. With his work, Elias restored the historical relevance of the dynastic household, and provided an incisive analysis of several aspects of court life. His powerful analytical framework, however, was based solidly on the anachronistic notion of a separation of the spheres of household service and state service. Thus, a relatively modern situation, the result of a long and uneven development, was projected backwards onto early modern history.

In recent decades many of the axioms related to the notion of 'absolute' rulership and the creation of a 'modern' bureaucracy in

\footnotetext{
2 See an early and intelligent variant of this thesis in Henri Brocher, A la cour de Louis XIV. Le rang et l'étiquette sous l'ancien régime (Paris 1934).
} 
the seventeenth century have been reviewed critically. State institutions were clearly gaining force, and increasingly penetrated society in terms of extraction of resources as well as coercive power. Paperwork, standard procedures and hierarchies gradually became more important from the later sixteenth into the later eighteenth centuries. Early modern rulership, however, remained limited in practice even where in theory it was presented as 'absolute'. Not only did the person at the heart of the machinery of state remain vulnerable; the centralized state itself consisted of competing layers, institutions and personalities, all necessarily working together with a variety of regional corporations. A confident ruler determinedly using the state apparatus could act with great authority and power; run of the mill government, however, was characterized by endless compromise rather than by authoritarian practices. The decline and loss of power of noble elites has likewise been questioned. Nobles lost their military autonomy and their independence as regional rulers, but many among them achieved key positions in the structures of the early modern state, both at the local and central levels. Magnates may have been drawn to the court-but by moving towards the centre they didn't necessarily lose power. Did the king-or the state, that somewhat abstract and deceivingly unitary notion-'domesticate' them, or did they take control of the state apparatus? Neither answer will do; the question itself is mal posée.

Clearly, however, a new balance between centre and periphery, between ruler and elites, was formed in early modern states. The court, comprising household as well as government, was the central theatre of that reorientation. Tracing the outlines of this process, as well as the layout of the institutional environment in which it took place, has served as the main agenda of a new generation of court historians. Their archival research has provided a wealth of new details, substantially revising the clichés connected to the image of Versailles. ${ }^{3}$ The revisionist views undermined the strength and cohesion of the older model, but did not lead to a clear alternative mode of analysis. Some general structures have nevertheless become clear. I will outline these

\footnotetext{
${ }^{3}$ References to literature have been kept to a minimum here; for relevant titles see my Myths of Power. Norbert Elias and the Early Modern European Court (Amsterdam 1995) and Vienna and Versailles. The Courts of Europe's Dynastic Rivals (Cambridge 2003). The current text follows some of the issues pursued in Vienna and Versailles, where more substantial description as well as references to primary sources are offered.
} 
in the first part of my paper, which forms a general reappraisal of the early modern European court. In the second part of my paper, I will come back to the question of 'domestication' and the balance between household and government. While this paper discusses themes relevant for all European courts, examples are taken from the French and Austrian Habsburg courts, where my own knowledge is concentrated.

\section{The Court: A Mobile, Changeable, and Multipolar Environment}

The eighteenth-century German erudite Johann Heinrich Zedler opened his learned description of the court with a succinct formula: 'Hof wird genennet, wo sich der Fürst aufhält'. Zedler's open formula underlines the variability of the court: rulers could be seen in many different contexts, surrounded by different persons. The 1694 Dictionnaire de l'Académie described the court as: 'la maison, les officiers, les principaux seigneurs, \& la justice ordinaire d'un roy, d'un prince''maison' itself covering dynasty as well as household and house. As a rule, contemporaries describing the court cite at least three dimensions: the palace, the ruler with his great nobles, and the ruler with his council. Subsequently, they often list a range of connected terms, related to courts of law, and to courtly manners-the latter invariably in the form of an ideal of politesse or refined manners as well as a critique censuring vanity, hypocrisy, flattery, intrigues, and moral laxity. Ideally, the dimensions of palace, nobles and government could fit together neatly: nobles forming the entourage of the ruler could serve him in the palace, and were expected to provide advice and support in governing the realm. In practice, we see two main functions at court, performed by overlapping staffs: a household catering for the ruler's personal needs, a staff overseeing the government of his realm. For both spheres of service, we find a differentiated group formed by a non-noble majority of lesser servants, and a smaller segment of nobles present at court that could expand rapidly on special occasions.

The balance between these two major component parts was further complicated by many other factors. First of all, courts retained great mobility throughout the early modern age. All courts developed a main winter residence in the course of the sixteenth and seventeenth centuries, usually in a major city that increasingly functioned as a capital. The Vienna Hofburg, a complex of buildings with medieval 
beginnings, continually adapted and expanded from the 1530's into its bloated early twentieth-century manifestations, may serve as an example. With the exception of Rudolf II, who moved his court to Prague, the Austrian Habsburgs remained loyal to Vienna, turning it into the courtly centre of their composite monarchy. The interaction of courts and capitals entailed the reconstruction and redecoration of many European cities, particularly those not holding prime positions before dynasties chose to grace them with their presences, such as Madrid or Turin. Bustling capitals such as London or Paris could never be dominated by the court to the same extent. Notwithstanding the prevalence of winter residences, we cannot depict early modern rulers as sedentary: in many respects they continued medieval forms of itinerant kingship. Movement necessitated by political and ceremonial meetings long remained important in 'composite' domains, where new rulers were expected to visit the various parts of their realm to be received there in person. In France, coronation and sacre took place in Rheims until the end of monarchy. Sixteenth-century kings, moreover, still initiated their rule with a 'tour de France royal', whereas deep into the eighteenth century, entries into major cities would be staged. Increasingly, however, the French court expected agents of the institutions and regions to come to the palace, and it no longer intended to go out and visit them systematically. For the Austrian Habsburgs, with their multiple titles pertaining to the Habsburg hereditary duchies, the crowns of Bohemia and Hungary, and the elective dignity as emperor of the Holy Roman Empire, travel remained an obvious necessity.

While the political necessity of movement slowly declined in relatively centralized states, other compelling reasons remained in force. Warfare and disease could require incidental travel. Louis XIV frequently traveled to the armies, for campaigns, maneuvers or mustering; Leopold I (1640-1705) fled from the Plague and unheroically sought to evade the Ottoman armies in the years around 1680. More importantly, all courts changed character and location following the seasons, with a high season for ceremony dominated by the Christmas and Easter cycles in winter and early spring and a low tide in summer when warfare demanded the presence of many courtiers doubling as officers in the army. The dominant royal pastime of the hunt dictated seasonal movement. Rulers would travel in early spring to visit a sequence of hunting lodges, returning only in late autumn for a protracted stay in the major winter residence. Indeed, only a core group 
consisting of servants as well as trusted secretaries would follow the ruler throughout the year. A reduced establishment catered for him in the hunting lodges; the bulk of administrative services stayed behind in the capital. Government services became sedentary before rulers and their immediate following did; financial and legal institutions that had gone 'out of court', literally leaving the palace precincts, would no longer follow royal peregrinations but pursue their routines in the ruler's absence.

After a protracted stay in the Hofburg, the Habsburgs would follow a trajectory including various palaces changing somewhat over time, including Neugebäude, Laxenburg, Favorita, and Ebersdorf. French kings followed a similar pattern, shifting from Parisian residencesLouvre, Tuileries, and Palais Royal-to Chambord and other favoured Loire châteaux, or alternatively to castles in the Île de France, such as Saint-Germain-en-Laye, Fontainebleau, or Compiègne-the latter conveniently situated halfway between Paris and Rheims. In his early years, Louis XIV often lodged in Saint-Germain, selecting it as his main residence in 1666. The move to Versailles in May 1682 did not turn his court into a static environment, but it did limit movement. The huge and expanding territories connected to Versailles, including the palaces of Trianon and Marly, offered enough opportunities for outdoor recreation throughout the year. After the last decades of Louis XIV's reign, longer sojourns other than the six-week autumn voyage de Fontainebleau did not recur on an annual basis. In the eighteenth century the voyage to Fontainebleau remained habitual, in addition to sojourns in Compiègne, and shorter stays in various smaller hunting lodges. ${ }^{4}$ In Vienna from the 1690's onwards, plans were developed to construct a Habsburg variant of Versailles: Schönbrunn. Only under Maria Theresa did these plans come to fruition, and even then Schönbrunn had to share its position with the more venerable Hofburg. Possibly a major outdoor 'palais d'état' was more relevant for rulers whose rich and splendid capitals tended to overshadow palace and court. ${ }^{5}$

As an institution the court had an everyday, permanent form, but on the basis of this usually relatively modest manifestation, it could develop into a staging ground for a variety of grand occasions. In the

\footnotetext{
${ }^{4}$ See Duindam, Vienna and Versailles, pp. 143-149.

${ }^{5}$ See Gérard Sabatier, 'Le palais d'État en Europe, de la Renaissance au Grand Siècle', in: Palais et Pouvoir de Constantinople à Versailles, Marie-France Auzépy and Joël Cornette, ed. (Saint-Denis 2003) pp. 81-107.
} 
sources, we find various terms distinguishing the modest permanent 'inner' court and the incidentally recurring but usually more exuberant 'outer' court: aula and curia; curia and curia solemnis; alternatively curia minor and curia maior or domus providentiae and domus magnificentiae. ${ }^{6}$ These various terms are related to presence as well as to rank: on top of a largely non-noble permanent daily service establishment for the ruler and his family, we find various higher-ranking echelons connected to the court, but not invariably present. As a rule, the basic tasks in the ruler's personal service, pertaining to the chamber, the table, and the stables, were performed by a hierarchy of servants, of which only the lesser-ranking groups were permanently present. The presence of higher honorary servants of noble stock was organized through more or less systematized forms of job rotation. Honorary servants were entitled to attend court in their official capacity, but were not as a rule present. They could attend court when their turn came, or when special occasions demanded their presence. Ordinances at the fifteenth-century Burgundian court, a pioneer in methodical job rotation, stipulated that only those actually serving their turn could live at court; others were not allowed to eat and lodge at the court's expense. $^{7}$

Each court had several categories of honorary officers; in France the gentilshommes servants (divided into panetiers, échansons and écuyers tranchants) and maîtres d'hôtel serving at the king's tables, or the equerries in the stables were major examples. In Vienna table servants responsible for carving meat, presenting bread and pouring wine and water were likewise present, but from the seventeenth century onwards chamberlains and councilors formed numerically far more important categories of honorary office. A nomination as chamberlain marked a person's entry into the ranking at court; nomination as a councilor (geheime Rat) promoted him into the next echelon of

\footnotetext{
${ }^{6}$ Bernd Ulrich Hegemöller, 'Die "solempnis curia" als Element der Herrschaftsausübung in der Spätphase Karls IV. (1360 bis 1376)' in: Deutscher Königshof, Hoftag und Reichstag im Späteren Mittelalter, Peter Moraw, ed. Vorträge und Forschungen XLVIII (Stuttgart 2002) pp. 451-476, see defining criteria of the solempnis curia on p. 459; the English convention, with the Steward's 'below stairs' staff as Domus providentiae and the Chamberlain's 'above stairs' staff as domus magnificentiae differs from the other distinctions, though it seems related to the same difference.

${ }^{7}$ For Burgundian examples see Holger Kruse, 'Die Hofordnungen Herzogs Philipps des Guten von Burgund' in: Höfe und Hofordnungen 1200-1600. 5. Symposium der Residenzen-Kommission der Akademie der Wissenschaften in Göttingen, Holger Kruse, Werner Paravicini, ed. (Sigmaringen 1999) pp. 141-165 at pp. 149-153.
} 
honorary membership of the court. Only a handful of such councilors actually advised the ruler in his councils: this was an honorary distinction rather than an actual duty. Presence at court, both for male and female youngsters, could start earlier. Youths with suitably noble pedigree could be educated at court: young boys as pages in the stables, and slightly older female teenagers in the following of a queen or empress. Their temporary service represented an initiation into elite life, a relatively brief phase leading to other careers often connected to the world of the court. ${ }^{8}$ At the highest level of honorary office, we find orders of chivalry. Every court in the course of the later Middle Ages and early modern age developed its own order of chivalry-or more usually a series of orders, pertaining to various domains of service. The structure was topped by one elite order which included the members of the dynasty-the Golden Fleece for the Habsburgs, the Saint-Esprit for the French court. The limited number of knights in these elite orders secured exclusivity; their annual series of activities formed a marked element in the court's calendar.

For greater occasions, more numerous as well as more prestigious servants were recruited. Service at the ruler's table, for instance, could be performed at many levels, from great ceremonial banquets, via public as well as more private dining in the state apartment, to a brisk meal in the safe seclusion of the cabinet, or 'sur sa serviette' on the road. Each form demanded a different array of servants. At the French court, the table staff featured a hierarchy of three offices labelled grand, premier, and ordinaire - a pattern reflected with some variation in the hierarchy of the staffs for chamber and stables. The highest office at court was that of high steward or grand maitre de l'hôtel (alternatively grand maitre de France); his noble substitute the premier maitre de l'hôtel was followed by a lesser-ranking proxy, the maître d'hôtel ordinaire. The maittre d'hôtel ordinaire, finally, was assisted by 36 honorary

\footnotetext{
${ }^{8}$ See on the female Hofstaat, female rulers and ladies-in-waiting an expanding literature, e.g. Jan Hirschbiegel; Werner Paravicini, Das Frauenzimmer. Die Frau bei Hofe in Spätmittelalter und früher Neuzeit 6. Symposium der Residenzen-Kommission der Akademie der Wissenschaften in Göttingen (Stuttgart 2000); Fanny Cosandey, La reine de France. Symbole et pouvoir xve-xviiie siècle (Paris 2000); Clarissa Campbell Orr, ed., Queenship in Europe. The Role of the Consort (Cambridge 2004); Katrin Keller, Hofdamen. Amtsträgerinnen im Wiener Hofstaat des 17. Jahrhunderts (Vienna; Cologne; Weimar 2005).
} 
gentilshommes servants and 48 maitres d'hottel. ${ }^{9}$ The procession of the king's viande from kitchen to table was a serious matter, with many participants, in a rich array of insignia and rituals ranging from the essai to the offering of the serviette. During banquets following coronations, marriages or other similarly important dynastic occasions, major princes of the realm would personally serve as panetier, échanson, and écuyer tranchant.

In Vienna, the Truchseß, Fürschneider, and Schenk, charges held by several persons, performed the duties parallel to those of the panetier, écuyer tranchant, and échanson. Chamberlains habitually served as cupbearer or carver when the emperor dined in his apartment; Hofdamen or court ladies served the empress during supper in her apartment. The full range of officers was present only on stately occasions when the sovereign's meal was witnessed by numerous spectators. Such meals were ideally attended by all noble courtiers and the entire corps diplomatique, while all suitably dressed visitors were allowed in to watch. The emperor and empress and their guests were served on bended knee, by an array of court officers. Eduard Vehse, a nineteenth-century erudite, calculated that any dish went through twenty-four pairs of hands before it actually reached the emperor. ${ }^{10}$ The emperor's table was marked by the pan-European insignia of sovereignty: it stood on a dais and his chair was crowned by a canopy of state. He would remain covered throughout the meal, taking off his hat only during prayers, or when the empress drank to his health. The most spectacular manifestation of public dining undoubtedly was the banquet following the imperial election and coronation ceremonies, an occasion attracting huge crowds into the city of Frankfurt. The audience first witnessed a curiously ritualized table service performed on horseback by the electors serving as 'archcourtiers of the empire' or Reichserzämter on the Römer square in Frankfurt. The imperial

\footnotetext{
9 These numbers remained stable after Louis XIV's reductions of the 1660's; in the 1640's and particularly the 1650's numbers had been far higher, see at http://www .zeitenblicke.de/2005/3/Duindam a brief internet overview with numbers and financial data, 'Vienna and Versailles. Materials For Further Comparison and Some Conclusions', zeitenblicke 4 (2005) Nr. 3 [13.12.2005].

${ }^{10}$ Eduard Vehse, Geschichte der deutschen Höfe seit der Reformation (Hamburg 1851-1860). Zweite Abtheilung: Oestreich. Geschichte des Österreichischen Hofs und Adels und der Österreichischen Diplomatie. particularly volume I-VIII (Hamburg 1851-1852) vol. VI, pp. 289-290; other sources in Duindam, Vienna and Versailles, pp. 176-177.
} 
marshal rode through a mound of oats, filling a silver container; the Truchse $\beta$ or seneschal carved meat from a roasted ox; the chamberlain followed with water and towel, the cupbearer with a cup filled with water and wine taken from a spouting fountain. After the proceedings, the populace was allowed to tear down and take home the attributes of the show-including the kitchen with the roasted ox, and wooden structures with rich textiles used for the procession from church to banqueting hall.

The honorary extensions of the permanent household were not limited to the noble upper echelons: priests, scholars, secretaries, musicians, artists, artisans, purveyors, labourers, and soldiers could likewise serve on an incidental basis, but still acquire the privileges that came with nominal membership in the court. In addition to the honour implicit in the connection to the court, members of the ruler's Hofgesinde, his 'court family', enjoyed freedom from regular legal and fiscal regimes. Clearly, both the mobility of the court and the differentiation between inner and outer courts make it difficult to establish the numbers of courtiers and servants. Do we count only the relatively small numbers present at court and listed in its payrolls, or do we include all persons in one way or another entitled to present themselves as belonging to the court? We find lists based on payment as well as lists representing nominal membership, with seriously diverging numbers. The wild estimates of numbers in contemporary sources as well as in the literature on the court reflect yet another problem. The court attracted visitors in many guises: high-ranking princes and nobles with their followings, petitioners, fortune-seekers, tourists. ${ }^{11}$ Should we measure a court at a high point of its recurring cycle of events, including all these groups, it would represent an overestimation of daily numbers.

Taking as a starting point the overviews generated by the court itself, including the main honorary officers, but excluding incidental visitors, an estimate of numbers can be given for the Austrian Habsburg and French courts from the sixteenth into the eighteenth century. Figure 1 represents the sum of the main court staffs (chapel, table, chamber, stable, hunt, guards) serving the French king and the Austrian Habsburg emperor from the 1550's into the later eighteenth

\footnotetext{
${ }^{11}$ Michaela Völkel, Schloßbesichtigungen in der frühen Neuzeit. Ein Beitrag zur Frage nach der Öffentlichkeit höfischer Repräsentation (Munich; Berlin 2007).
} 


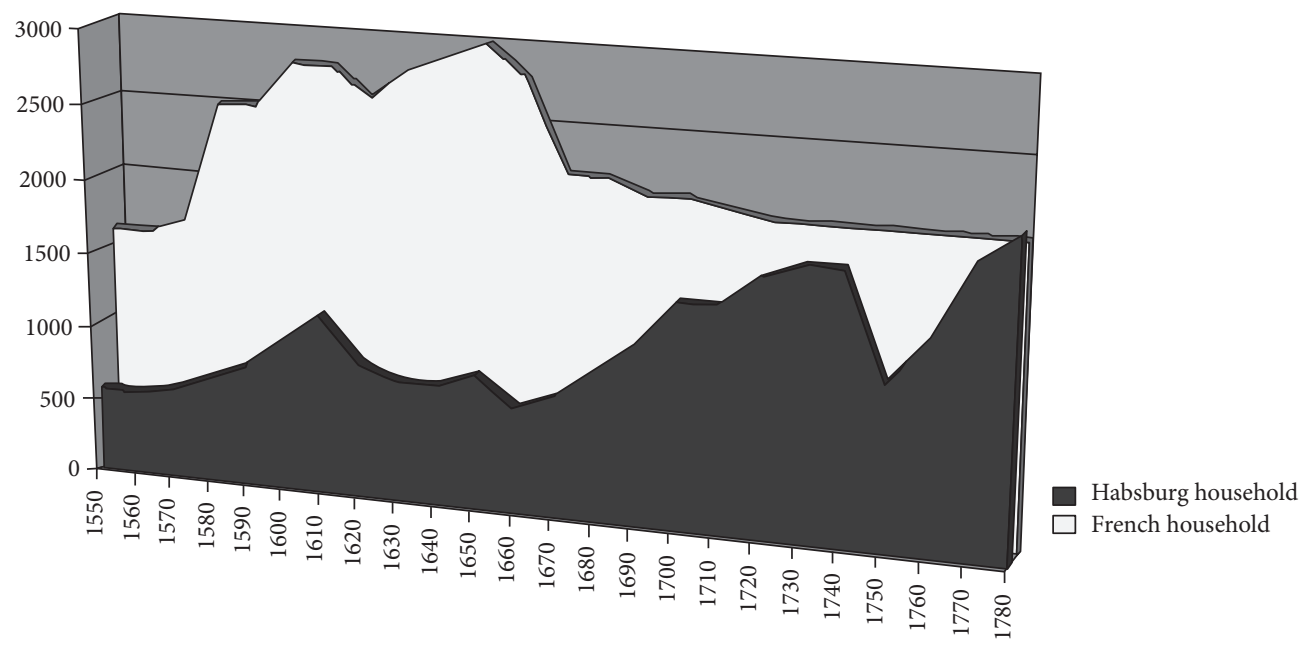

Figure 1. Numbers of the rulers' core staffs at the Austrian Habsburg and French courts

century; numbers are tentative for the first century, more reliable for the latter phase.

Both courts show a jagged curve, with numbers diverging sharply in the sixteenth and early seventeenth century, slowly converging in the course of the eighteenth century. After a steady rise in the early sixteenth century the French court exploded in the phase of religious wars; a brief attempt to reduce numbers under Cardinal Richelieu couldn't prevent another round of spectacular inflation in the 1640's and 1650's, during the regency of Anne of Austria and the Fronde. Louis XIV in the course of the 1660's effectively reduced and stabilized numbers around 2,000-a level that would roughly be maintained until the sharp reforms and reductions of the 1780's. The Austrian Habsburg court experienced a brief phase of inflation towards the end of the Prague-based reign of Rudolf II (1552-1612)-typically, again in years of crisis rather than in years of stability. On the whole, it increased gradually from 600 to 800 , expanding more rapidly only in the reign of Leopold I, who allowed the numbers of chamberlains and later councilors to explode. Expansion continued under Charles VI (1685-1740) and his daughter Maria Theresa (1717-1780), though the combination of succession crisis and warfare led to an abrupt drop in the 1740 's. In the later eighteenth century numbers came close to 2,000 . 
Several points need to be made on the basis of these numbers. First of all, we should take for granted that while regular staffs tended to grow steadily but slowly, honorary office could expand and decline sharply, following the curve of political developments. Crisis led to expansion, with rulers as well as major courtiers attracting friends and followers to the court, rewarding them mostly with honorary offices and titles. Typically, the French king Henry III (1551-1589) in the 1570's repeatedly argued that he himself had to confirm all appointments to court office, demonstrating that his Guise rivals, holding several high court offices, had willfully neglected this rule. A similar situation, with courtiers inviting in their own protégés, helps to explain the expansion of the court under Rudolf II. Reducing the court after numbers had inflated proved particularly difficult for the French kings. They had started selling offices, and hence needed to provide financial compensation for those they wanted to send away-a hard challenge for structurally impecunious rulers. This predicament furthered the tendency towards hereditary of court offices at all levels, based on repeated payments into the king's coffers. French court lists in the first half of the seventeenth century somewhat wearily repeat the intended abolition of supernumerary offices, using the formula 'vacation avenant': upon the death or departure of the incumbent. The great reductions in the 1660 's had become almost inevitable by the final peak of inflation in the 1650 's, yet they clearly demonstrate that Louis XIV held the reins of power securely in his hands. The Sun King proved his strength not by indiscriminately including people in his court, but by sending most of the hangers-on away.

The Austrian Habsburgs never openly and systematically sold court offices in any rank or staff. Their court adhered to a traditional feudal pattern, in which all court officers and servants would nominally lose their place upon the death of the emperor. The successor would confirm most of them in their positions, but could within certain limits refrain from doing so. All honorary officers likewise had to be reconfirmed. As a rule a new emperor installed his own intimates and servants in the highest echelons of court service, confirmed the daily staffs at court, and nominated new honorary officers on the occasion of special dynastic festivities. Allowing inflation of numbers, thus, was less troublesome for the Habsburgs than it would have been for French kings, who took their place in an already existing court, in which they could make only limited changes because of the impact of heredity and venality. 
One last important point must be made about the aggregates of court staffs given here. ${ }^{12}$ Generally, we picture the court as a more or less unitary or unifocal structure organized around a single sovereign. This matches the increasing emphasis on undivided sovereignty and primogeniture evident in the early modern European context. We have to keep in mind, however, that in practice the ruler's relatives as well as his spouse had their own households; the same held true for the major nobles of the realm whether or not they stayed at court. Ferdinand I (1503-1564) still chose to divide his heritage among his sons, starting two junior Habsburg branches in the Tyrol and Styria, to be reunited to the main line only in the course of the seventeenth century. In late sixteenth century, the French king's younger brothers expanded their households as did the king, and even adopted offices mimicking the dignity of the state, such as the introducteur des ambassadeurs. ${ }^{13}$ On the whole, in the seventeenth century, rulers were better able to secure their pre-eminence among their relatives, and certainly less inclined to divide their heritage; yet they still accepted the necessity to place their relatives in a suitably dignified environment.

'The' court, then, consisted of a series of households, located in various palaces. Louis XIV's brother Philippe d'Orléans and Philippe's spouse, the Palatine princess Elisabeth Charlotte resided in the palace of Saint-Cloud. In 1699, Philippe's household numbered 830 persons; his wife's following numbered another 242 persons. They formed the most substantial of a series of similar establishments. While women were only marginally present in the ruler's predominantly male household, they served on a regular basis in the households of the female members of the dynasty. The queen's household in France formed a parallel of the king's with most staffs present on a smaller scale, plus a substantial female following consisting of several categories of court ladies and female servants. In all, she was usually served by more than

\footnotetext{
${ }^{12}$ For the sake of brevity and clarity I leave out the presence of substantial military units around court, part of them as constituent elements in the maison militaire of the French king. This institution never developed to the same extent under the Austrian Habsburgs, although they did add more elite guard units to their court in the second half of the eighteenth century. See Guy Rowlands, 'Louis XIV, aristocratic power and the elite units of the French army', French History 13 (1999) pp. 303-331; Michael Hochedlinger, 'Mars ennobled. The ascent of the Military and the Creation of a Military Nobility in Mid-Eighteenth-Century Austria', German History 17 (1999) pp. 141-176.

${ }_{13}$ Duindam, Vienna and Versailles, p. 52 on Anjou and his 'sovereign' household officers.
} 
500 persons. The ruling empress in Vienna headed a much smaller establishment, consisting of ladies-in-waiting, female servants, and a small male household, totaling between 60 and 80 persons. The dowagerempress, however, was served by a 250 -person establishment, expanding further in the later seventeenth century. Travelers visiting Vienna in the later seventeenth century were impressed by the Italianate splendour and cultural patronage of the dowager-empress Eleonora II Gonzaga's court. In addition to the dowager-empress, the only other sizeable separate establishment in Vienna was that of the King of the Romans, chosen during his father's lifetime as emperor-elect, waiting for his turn to ascend to imperial dignity. In this position, he gradually built up his own household, forming a basis for his later court and government. Joseph I's (1678-1711) household expanded to more than 400 during the 15 years he had to wait before succeeding after his election in 1690. The French Dauphin or heir-apparent, however, would no longer have his separate household after Louis XIII. Louis XIV reached maturity long after his father's death; his son Monseigneur had his menins or boon companions, in addition to a special staff for hunting, but on the whole was served by his father's staffs. Surprisingly, the Dauphine, usually a foreign princess, did have a major household of her own-only the Dauphin, the person closest to his father's sovereign position, was denied a personal household.

On the whole there were fewer secondary households in Vienna, and they were smaller: the grand total of all secondary households around court was far higher in Versailles. This may have been a consequence of dynastic demography more than of conscious dynastic policies. Maria Theresa effectively changed the traditional situation by merging the various dynastic households. This attempt, however, led to the temporary doubling or even tripling of senior household offices, because sending away trusted servants was not deemed acceptable. In the course of the eighteenth century, secondary households proliferated at the French court because of the expanding royal family, turning Versailles into a rather crowded place with a seriously reduced potential for accommodating courtiers. ${ }^{14}$ During the reforms of the

\footnotetext{
${ }^{14}$ See three studies by William Ritchey Newton based on his extended knowledge of eighteenth-century apartments and their occupants, L'Espace du roi. La cour de France au château de Versailles 1682-1789 (Paris 2000); La petite cour. Services et serviteurs à la cour de Versailles au XVIII siècle (Paris 2006); Derrière La Façade-Vivre Au Château de Versailles Au xviii ${ }^{e}$ Siècle (Paris 2008).
} 
1780 's the proliferation of secondary households was taken in hand, in a drawn-out and precarious process. Typically, Louis XVI curtailed his own staffs, but could not convince his queen to do likewise, and had difficulties in persuading his two headstrong brothers to follow his example. The king or emperor was the formal leader of the realm as well as of his house; the other households under his umbrella, however, played an important role as alternative centres of patronage, and sometimes as the core of rival factions. Tensions between fathers and sons, between ruler and brothers (or their offspring), and more generally among those sharing in the sovereign status of a ruling house, had a notable and lasting impact on other forms of political contention at court. ${ }^{15}$

How can we restore some coherence to the splintered image of a court determined by mobility, changeability, and multipolarity? Clearly, almost all European courts shared a similar structure of staffs, with table, chamber and stables as the three central staffs, immediately followed by the often more diverse establishments for guards and hunting. A religious establishment was present at all courts, but it was fitted into the institutional structure in many different ways. The steward, chamberlain and master of the horse were almost universally the three pre-eminent nobles serving at court in Europe. The marshal, symbolizing the connection with the army and with justice, was markedly present at German courts, where he frequently followed the steward or Hofmeister as second-in-rank, and sometimes even preceded him. Service in the chamber tended to promote lesser figures to higher rank-from antiquity to modern times, notorious favourites would emerge in the immediate privacy of the ruler's chamber. Chamber staffs were also most likely to change, with new intermediary layers or offices arising according to the new ruler's personal preferences. The introduction of the 'Scottish' bedchamber under James VI at the English court, the rise to prominence of the sumiller de corps at the sixteenth-century Spanish court, or the proliferation of offices in the French chamber and wardrobe can serve as examples. The numerous high offices in the French chamber and wardrobe, with their troubled hierarchical relationships, may have developed simply as an

${ }^{15}$ Emmanuel Le Roy Ladurie, 'Auprès du roi, la Cour', Annales ESC 38, 1 (1983) pp. 21-41; 'Système de la cour (Versailles vers 1709)', L'Arc 65 (Aix-en-Provence 1973) pp. 21-35 stressing rivalry in the dynasty-a point taken up in the general introduction of this volume. 
ad hoc response to urgent demands for office in the ruler's proximity. Court ordinances indicate that the major staffs long retained a strong sense of autonomy, with the principals priding themselves on their personal relationship to the ruler, symbolized by the oath 'entre les mains de sa majesté. They would accept orders only from the king in person, or from his direct representatives. Hierarchies among these highest officers, particularly at the French court, were never clear or generally accepted.

Within each of the staffs at court, three echelons can be identified. At the top, we find a very small and exclusive upper layer of court dignitaries leading their staffs, including high steward, chamberlain, master of the horse, marshal, guard captains, the grand veneur and his colleagues in the hunt, the almoner or other functional equivalents in the chapel. They had substitutes of lesser standing, but did not usually share their responsibilities with equals on the basis of job rotation Only the four prestigious French premiers gentilshommes serving a full year in alternation in the chamber, and the two lesser-ranking but still important maîtres de la garderobe serving under a single grand maitre de la garderobe on a semester-basis appear to form an exception to this rule. This handful of highest courtiers, almost inevitably of high noble stock, formed the apex of status and prestige in France as well as in the Habsburg lands. No sharp line can be drawn between the first echelon and lesser noble officers, who didn't share their office on the basis of job rotation, but clearly all officers pledging their oath with the king or emperor in person need to be included in the upper echelon.

The noble honorary officers performing occasional temporary service in one of the court staffs, by definition sharing their position with numbers of others, can be seen as a second echelon universally present at the early modern European court. The nature and organization of their connection to the court could vary immensely, but we can distinguish them easily both from the small upper layer of the major court officers, and from the numerous non-noble service establishment catering for basic daily services. Sharply diverging practices vis-à-vis the nomination of honorary officers characterized the courts of Vienna and Versailles: in Vienna numbers started to explode when in France they were reduced. Leopold's generosity, however, was not very expensive and in retrospect decidedly useful. Only the small numbers of actually serving chamberlains were paid. At the same time, all nobles keen on entering the court's ranking and the court's higher nominations had to proceed through the two-tiered ranking 
system formed by chamberlains and councilors, precedence in each rank organized on the basis of seniority. This system underlined the indisputable impact of the imperial nomination into these ranks, at a time when the prestige of the title of chamberlain had sustained serious depreciation because of increasing numbers. The ranking also gave a measure of clarity and tranquility to the court's internal contentions about precedence; conflict remained typical, but it never reached the Hobbesian proportions of the French court, where servants and courtiers seemed permanently busy scheming to improve the status of their offices, preferably at the cost of others.

The third echelon, the most varied and usually by far the most numerous part of the court, consisted of non-noble personnel in the multiple services catering for dynasty and palace. Educated scholars, trained specialists and artisans stood at the upper limit of this groupnotable among them musical virtuosi, or painters of name and fame. They could in practice count among the ruler's intimates, and in that sense were not so distant from the first echelon. Louis XIV explicitly allowed Jean Baptiste Lully privileges usually reserved for highstatus courtiers; Leopold engaged in intimate correspondence with his learned librarian Lambeck. Usually servants in all staffs, however, remained at a greater distance from the ruler as well as from his high noble servants. They counted among the commensaux $d u$ roy, or members of the emperor's Hofgesinde, and hence were entitled to food and accommodation. This core of the household establishment hardly fits Castiglione's image of the courtier: yet these 'below stairs' servants were numerically dominant as well as characteristic for the atmosphere of life at court. A measure of conviviality must have existed between the various layers at court; early arrangements for dining, with their hierarchical positioning of tables and proportioning of food, also lay down the shifts of people eating at court, with the leftovers of the highplaced being in turn consumed by lesser servants. Possibly the worlds of noble as opposed to menial service became more sharply separated in the course of the early modern age. Louis XIV's reduction of the court in the 1660's not only concerned the honorary officers: the king also purged the ranks of the lower commensaux du roy. He sent away many servants, only to hire them again on the basis of commissioned labour without the status and rights connected to court office-a procedure not unlike modern 'outsourcing'. The status and privileges of honorary officers as well as lesser non-noble servants maintained at court by the king were consolidated and improved. In fact even the 
lesser ranks of servants could aspire to achieve noble status through their court service.

The third echelon of the household also had many connections in the outside world, and acted as intermediary between the 'economies' of court and city. ${ }^{16}$ Purveyors and artisans found their name and reputation enhanced thanks to their service to the dynasty-as the indication 'K.u.K.', imperial and royal, still indicates in Viennese streets. The financial protocols of the court suggest a dense traffic in finances, labour, and products connecting city and court. A recent study lists thousands of artisans and workmen related to the court. ${ }^{17}$ The nonnoble dimension, numerically dominant at court, and strongly present in the city, was long forgotten by court historians, who usually focused on the elites pictured in Castiglione's salon-like depiction of the court. It deserves to be restored to its fundamental role in the household as well in the urban environment of the court.

\section{Domestication}

Each of the three echelons of the household relates to different themes of research: decision-making and patronage for the upper layer, integration of regional elites for the second layer of honorary extensions, and finally the artisanal and urban connections of the court for the third layer of non-noble service. None of the three fits easily into the traditional image of the courts, as a prison for nobles rendered powerless.

Domestication can be described the 'taming' of the nobles, turning them from an independent warrior-elite into a reduced palace elite of domestics. As a corollary, in the ruler's immediate dependence these

${ }^{16}$ John P. Spielman, 'Status as commodity. The Habsburg Economy of Privilege', in: State and Society in Early Modern Austria, Charles Ingrao, ed. (West-Lafayette 1994) pp. 110-118 and his wide-ranging study of quartering in Vienna: The City \& the Crown. Vienna and the Imperial Court 1600-1740 (West Lafayette, Indiana 1993).

${ }_{17}$ Herbert Haupt, Das Hof- und hofbefreite Handwerk im barocken Wien, 1620 bis 1770. Ein Handbuch (Innsbruck; Vienna; Bozen 2007) Forschungen und Beiträge zur Wiener Stadtgeschichte 46; see also Susanne Claudine Pils and Jan Paul Niederkorn, eds., Ein zweigeteilter Ort? Hof und Stadt in der frühen Neuzeit, Forschungen und Beiträge zur Wiener Stadtgeschichte. Publikationsreihe des Vereins für Geschichte der Stadt Wien, Band 44 (Vienna 2005); Werner Paravicini and Jörg Wettlaufer, eds., Der Hof und die Stadt. Konfrontation, Koexistenz und Integration im Verhältnis von Hof und Stadt in Spätmittelalter und Früher Neuzeit, Residenzenforschung Band 20 (Ostfildern 2006). 
tamed elites adopted more refined and subdued forms of behaviour. Elias, in fact, presented his detailed study of the court as the main example for his grand psychohistory, Über den Prozeß der Zivilisation. In this important two-volume study, he outlined the late medieval and early modern Verhöflichung der Krieger (awkwardly translated as 'courtization'), based on the changeover from external coercion (Fremdzwänge) to internal ideals and controls (Selbstzwänge) and the concomitant rise of Affektbeherrschung-a more optimistic variant of Freud's notion of Triebverzicht. Domestication represents a vital component in the chain of developments finally leading to the Verhöflichung of the warrior-elite. In its turn, domestication can be divided into several elements, such as financial dependence, residence at court, political isolation, and dependence on court-created hierarchies or court culture. Some of these elements are undeniably present in the context of the early modern courts, whereas others are more problematic, or even plainly mistaken. It is necessary to briefly reassess the coherence of the domestication thesis on the basis of the more differentiated picture of the court presented here.

First of all it is clear that rulers were hardly interested in drawing 'the' nobility into court. They were keen mostly to attract into their orbit the highest elite echelons, potential rivals outside the ruling dynasty as well as members of the dynasty. Ritual domestic service of such high nobles, while demonstrating their subservience and loyalty to the ruler, should not in itself be seen as a demeaning activity: it confirmed the high rank of the honorary attendants as much as it showed the pre-eminence of the ruler. Other groups would more likely find access to the court difficult, and certainly could not as a rule become regular attendants eating at the king's tables. To be successful in accommodating the grandees, rulers had to prevent the dignity of the court from being undermined by an excessive inflation of honours, hence their permanent though often futile attempts to reduce numbers. Only an exclusive environment, conspicuously underpinning the high rank of its members, could induce grandees to attend or hold high office at court. Domestication, therefore, cannot simply be connected to growing numbers. As stated before, expansion of courts indicated political turmoil rather than stability, open competition at court rather than the dominance of a resolute ruler. As soon as courts expanded beyond a critical point, the ruler's coffers were emptied whereas at the same time the dignity of the court declined. 
A closer look at physical presence at court-a returning element in the gilded-cage thesis-underlines the same point: it necessarily remained limited to small groups. Versailles, with its exceptionally large and diverse facilities, housed an approximate 3,000 logeants, court staff with usually exceedingly modest apartments in one of the buildings in the complex. ${ }^{18}$ Nobles holding high court office could expect to be accommodated decently in the more prestigious buildings, but might still prefer their own country seats, or more likely their Parisian and Versailles-based houses. In the 1690's, after the brilliant opening decades of Versailles, Paris regained its cultural prominence; in the morose and financially hard-pressed first decade of the eighteenth century Versailles lost much of its remaining appeal. It would never entirely regain its position after the intermezzo of the regency and Louis XV's (1710-1774) minority. In the course of the eighteenth century, the expanding dynasty itself required most of the more sumptuous apartments in Versailles. As many courtiers held court office in combination with other high offices in regional government, army command, and diplomacy, their presence was always temporary. ${ }^{19}$ Following a pattern common in the sixteenth and seventeenth centuries, the Viennese court into the eighteenth century was based on a system of billeting courtiers and servants of all ranks in the city. Accommodation in the palace was limited to the dynasty and a very small number of intimate servants. Nor were the diverse groups on the court's payroll, or specifically the upper noble layers and honorary servants necessarily engaged in daily interaction. The dynasties' activities determined the presence of courtiers, servants, and spectators in different settings; there was no ongoing series of salon-like social occasions at court before the later eighteenth century. Presence at court and 'court life', therefore, need to be understood as a chain of events in a calendar repeated annually with minor variations, rather than as a permanent set-up. Only very gradually did 'court life' evolve from the incidental

${ }_{18}$ Newton, L'Espace du Roi provides a welter of information on the logements in the palace, yet no assessment of the overall capacity of the palace and surrounding buildings; see estimates of the logeants in Jean François Solnon, 'Cour', in: Dictionnaire de l'Ancien Régime, Lucien Bély, ed. (Paris 1996) p. 356: 3,000 logeants in Versailles.

${ }^{19}$ See Leonhard Horowski, 'Pouvez-vous trop donner pour une chose si essentielle? Eine prosopographische Studie der Obersten Chargen am Hof von Versailles', Mitteilungen der Residenzenkommission 11, 1 (2001) pp. 32-53 and his major forthcoming study on courtiers and their careers 1660-1789, to be published in the Pariser Historische Studien-series of the German Historical Institute in Paris. 
high points of the ruler 'holding court' with his grandees, to an annual, weekly and finally almost daily pattern of social activities. The French court, traditionally cultivating a convivial and accessible style of court life, pioneered this development, taken over by other courts in the eighteenth century.

Did nobles flock to the court because they were poor? Indebtedness was a common phenomenon in a group based on hereditary status and landed wealth, though temporary pennilessness could go together with long-term solvency. Supplementary sources of ready cash were quite welcome: service in the armies, at court, in government, and in the church had long since provided these for nobles, prevented from engaging in commerce by the strictures connected to their hereditary status. The court, however, was an insecure source of income. Wages were low, and frequently went unpaid. Extras could be enormous, but such windfall profits reached only the very fortunate. Financial backgrounds of court service vary widely: rulers could attract high nobles to court service by paying them lavish pensions in addition to their wages. On the other hand, we regularly find lesser-ranking aspirants paying substantial amounts to the ruler with a view to obtaining office. This could be done discreetly, without any obvious connection between the payments offered to the crown and the accession to high office, or in more open and organized forms of venality. The advantages of obtaining a court office could convince rich nobles aspiring to greater honour to pay handsomely; conversely their more prestigious fellownobles might hesitate to accept office if it would not be accompanied by lavish rights and advantages.

On the whole, the small upper layer of nobles serving at court was far more likely to seriously benefit financially from service than the more numerous layer of honorary officers. At the French court, the upper layer of court officers had turned the rights and benefits connected to their semi-venal and semi-hereditary offices into financially lucrative ventures, even without counting the king's incidental graces, or payments made by diplomats and petitioners to secure their support. Among these families, some strengthened their independent sources of mostly landed income in the process, whereas others increasingly depended on the various incomes generated by their court establishment. In Vienna no hereditary rights to the highest court offices developed: novices even from the upper crust of noble families had to start at the lower honorary rank of chamberlain. A solid financial basis was a prerequisite for entering court service as a nobleman. Investments 
were necessary to effectively perform service with sufficient dignity, whereas rewards could only be expected at higher levels, and were not to be taken for granted. Financial support, hence, cannot be seen as the main incentive for high nobles to enter court service in Vienna. In the French case the dependence of high nobles on their court-created incomes was greater, but here the rapid development of venality and hereditary rights seriously limited the king's potential to actively use his grace as an instrument to include or exclude whom he saw fit. We have many examples of overspending grandees being supported by the king's or emperor's largesse; on the other hand, rulers likewise often found financial support among their noble servants. ${ }^{20}$ The financial nexus linking rulers and their highest echelon of courtiers cannot simply be presented in terms of the courtiers' increasing dependence.

Risks and benefits were different for the intermediate echelon of honorary noble servants. They formed a pool from which the talented and driven could be chosen for more rewarding positions and honours, but this lottery necessarily disappointed most. Attending court, in their case, could indeed mean investing family finances in dress and other marks of high status without receiving any serious material compensation. Clearly, the benefits of court service for this second echelon can in no way be compared to those of the upper layer. It was quite possible for these temporary courtiers, moreover, to overspendand in their case, rulers were less likely to step in and pay the bill. In terms of 'taming rivals', however, this group was not as relevant as the first echelon. The staff in the lowest echelon received meagre wages, though the court usually provided some extra support in the form of small pensions for incapacitated or elderly servants, and widows. Servants were often able to use their position at court to generate extra income by asking gratuities from visitors and tourists before granting them access or leading them through the court-a practice frowned upon but tolerated by rulers who didn't have the means to pay decent salaries. Servants, artisans and soldiers in the lower ranks at court also profited from their exemption from fiscal and legal regimes, sometimes by practicing trades illegally without paying the regular urban dues. The protocols generated by the perpetual petitions sent to the emperor by servants at the Viennese court give a lively image of their

${ }^{20}$ Daniel Dessert, Argent, pouvoir et société au grand siècle (Paris 1984) shows that high nobles were involved in financing the state through intermediaries. 
hardships, opportunities and quarrels. Only the very special servantspainters, musicians, incidentally scholars-could hope to reach comfortable levels of wealth through their court functions; virtuosi in the musical establishment were among the best-paid persons at the Habsburg court.

The separation of grandeur from pouvoir, of prestige from political power, or household from government and courtiers from ministers, occupies a key position in the domestication thesis. It finds support in the unquestioned growth, differentiation and professionalization of administrative services around the ruler. The domains of council and household were institutionally separated to a large extent. Separate services pertaining mostly to finances, law and warfare were set up; chancelleries and proto-ministries developed. They usually operated in the palace or its immediate vicinity, sometimes in separate buildings such as the ailes des ministres in Versailles or the Reichskanzleitrakt in Vienna, but tended to move to more distant locations in the course of the eighteenth century-repeating a trajectory followed earlier by institutions such the Parisian parlement or sovereign court of law, 'going out of court' in the later middle ages. The central bureaucracies remained relatively small in early modern Europe. The six French central 'ministries' counted fewer than 700 servants until the Revolution, when numbers rapidly expanded-even Louis XIV's brother's household numbered more servants than the aggregate of these agencies of the state. In the Austrian Habsburg domains, numbers were even lower, though a gradual and ongoing rise characterized the eighteenth century, accelerating under Maria Theresa and Joseph II (1741-1790). During the brief personal reign of this intriguing monarch (17801790), the bureaucracy went beyond the household in numbers.

Even when ministries or specialized councils developed into sedentary separate bodies, housed in their own buildings and increasingly distant from the domestic context of rulership, final decisions were usually taken in the ruler's cabinet or council room, frequently in the proximity of, though not necessarily in consultation with, noble court officers. Louis XIV barred high nobles and cardinals, the two notorious categories of favourites in the preceding phase of political crisis, from his inner privy council. His purge was neither complete nor lasting: high noblemen soon entered the council, and in the eighteenth century also repeatedly served as sécrétaire d'état or minister. His initiative remained the exception rather than the rule, which envisaged a wise mix of specialized administrators and high nobles in the exclusive 
highest council. In Vienna, the high steward routinely chaired the emperor's privy council into the eighteenth century, though in the later eighteenth century executive administrative officers became more dominant, and a tendency towards political marginalization of the household did appear.

The leading officeholders among the new state servants had first pledged their oath with their traditional superior the chancellor, but in the course of the later sixteenth or seventeenth century they would typically be promoted to the personal oath with the ruler. In this respect, these ennobled state servants gradually achieved an uneasy parity with the greater courtiers. The balance between the two categories of servants could vary widely. French grandees were not as a rule tempted to meddle with details of law and finance; they were keen on the highest executive offices of the state, but unwilling to learn the trade by devoted study and a gradual procession through the bureaucratic ranks. Their Habsburg compeers proved far more willing in both respects, study and advancement through administrative career. Hence, in Vienna no strong and lasting formation akin to the noblesse de robe emerged: a varied group of noble families dominated household as well as government, and accepted the intrusion of a handful of isolated social climbers without signs of great distress. In France, the most successful dynasties of state servants, the 'robe de conseil', gradually mixed with noble courtier dynasties-scions of the two ministerial dynasties of Colbert and Le Tellier would hold court offices just below the upper ranks from the later seventeenth century onwards. Apparently, for these conspicuously successful bureaucrats, court office still represented the acme of social success.

The increasing institutional separation of household and government, in France strengthened by a relatively clear divide in social background of families active in these domains, provides some support for the domestication thesis. It is based, however, on a limited and anachronistic reading of institutional and political structures. In the context of a debate about Tudor England, a useful corrective was put forward by David Starkey, who underlined in his works that access and proximity to the ruler almost necessarily entailed power. ${ }^{21}$ Positions

${ }^{21}$ See e.g. David Starkey, 'Representation through Intimacy. A Study in the Symbolism of Monarchy and Court Office in Early-Modern England', in: Symbols and Sentiments. Cross-Cultural Studies in Symbolism, Ioan Lewis, ed. (London 1977) 
in the emerging bureaucracies, moreover, depended on professional capabilities as well as on personal prestige and easy access; they could dwindle to insignificance if the incumbent proved inept in any of these respects. High noble courtiers functionally enjoyed personal access to the ruler, and frequently became his intimate advisers without holding formal office in the bureaucracy. Access didn't necessarily lead to power in the formal processes of decision-making; neither did it always bring the friendship of the ruler. This small group, however, through its functions determined access to the ruler in domestic settings, and was well placed to influence patronage. Moreover, high courtiers enjoyed extensive rights of nomination themselves, which in fact allowed them to use to court as a basis for supporting their dynastic networks of clientage. ${ }^{22}$

In practice, courtiers were keen to exert a direct influence on decision-making mostly when important regional or dynastic interests were at stake, or in times of instability and civil strife. Succession crises, regencies and minorities offer a structural example of such phases, the religious turmoil of the later sixteenth and early seventeenth centuries a more incidental though particularly disruptive and long-lasting example. On the whole, the interest of courtiers' families and regional alignments-with clients eagerly waiting for their patron's successes at court-were dominant, and this meant that establishing some control over the distribution of honours was their first priority. The level of 'micropolitics' was more important than the level of great decisions of state. ${ }^{23}$ Rulers, on the other hand, invariably listed a direct personal control over the distribution of honours among the highest priorities of rulership. ${ }^{24}$ Petitioners swarmed the halls and courtyards of European

pp. 187-224, and a volume edited by him: The English Court from the Wars of the Roses to the Civil War (London; New York 1987).

${ }^{22}$ See e.g. on Condé Katia Béguin, Les princes de Condé. Rebelles, courtisans et mécènes dans la France du grand siècle (Paris 1999); on Condé's court patronage Christophe Blanquie, 'Dans la main du Grand maitre. Les offices de la maison du roi, 1643-1720', Histoire \& Mesure XIII, 3-4 (1998) pp. 243-288.

${ }_{23}$ 'Mikropolitik' refers to the work of Wolfgang Reinhard and his pupils, characterized by careful research of family connections and nominations, and a stress on this level of interest-related strategies rather than on grosse Politik-hence a tendency related to the examples of Lewis Namier and Ronald Syme.

${ }^{24}$ See e.g. on Philip II and Louis XIV, H.G. Koenigsberger, 'The Statecraft of Philip II', in: Politicians and Virtuosi. Essays in Early Modern History (London 1986) p. 81; Duindam, Vienna and Versailles, pp. 228-229; Charles Dreyss, ed., Mémoires de Louis XIV pour l'instruction du Dauphin, 2 vols. (Paris 1860) vol. 2, pp. 341-342. 
courts, waiting for a chance to be heard, for a person willing to intercede in their favour. Clearly, access was a cherished commodity here, and control of access a vital sinew of power in the hands of courtiers. Taking account of the nature of early modern rulership and political culture, therefore, it makes no sense to picture courtiers as 'outsiders'. Power and influence at court, the duke of Luynes suggested in 1754, demanded contacts in the council as well as among the 'courtisans qui approchent du roi'. ${ }^{25}$ Court factions recognized this principle, and sought support among both groups. Clashes among courtiers and state servants were endemic particularly at the French court, but as a rule alignments were based on rivalry among persons with similar backgrounds, rather than on the supposed compartmentalization of household and government.

In each of the themes discussed-numbers of courtiers, presence at court and 'court life', financial dependence, political isolationthe domestication thesis overstated one tendency at the cost of other equally important developments, and it also failed to differentiate between the different echelons of staff at court. One final and important aspect remains to be discussed: the impact of the court on noble hierarchies, aptly termed by one historian the 'economy of honour'. ${ }^{26}$ Rulers could selectively elevate their servants to noble rank; they could include intimates into orders of chivalry, and support and reward more distant clients in a variety of ways. Without accepting the onesided image of penniless full-time courtiers brought together in the palace under the wary eye of the ruler, we can only acknowledge the remarkable impact of honours and nominations emanating from the court. These distinctions had the immense advantage that they in no way demanded permanent presence at court and payment from the ruler's coffers. People could obtain titles or honorary offices during a short stay at court, or even during the ruler's visits to their territories. While they obtained a nominal membership of the court, and the right to be present as a participant rather than as a spectator, they could stay at home and perform incidental part-time service. At the same time,

${ }_{25}$ Charles Philippe d'Albert, duc de Luynes, Mémoires du duc de Luynes sur la cour de Louis XV, L. Dussieux, Eud. Soulié, ed., 17 vols. (Paris 1860-1865) vol. 13, pp. 430431, 436-437, July 1754, quote on p. 437 about Pierre-Marc de Voyer de Paulmy, comte d'Argenson, secretary for war, and Jean Baptiste Machault d'Arnouville, controleur-général and garde des sceaux.

${ }_{26}$ Andreas Pečar, Die Ökonomie der Ehre. Der höfische Adel am Kaiserhof Karls VI. (1711-1740), Symbolische Kommunikation in der Vormoderne 5 (Darmstadt 2003). 
their court title became an important element in local ranking. The Baron de Pöllnitz, an indefatigable eighteenth-century travel writer, noted that a Bohemian court chamberlain's wife enjoyed precedence over the spouses of nobles whose husbands didn't enjoy this rank. ${ }^{27}$ Such court-related noblemen, of course, were also more likely to benefit from the ruler's patronage. Local noble society and noble government were increasingly oriented towards the centre, even where the presence of central institutions remained insubstantial. A conspicuous court, in other words, would allow relatively lean and cheap structures of government, because it made possible a reliance on the administrative capacities of loyal, court-oriented, local elites.

Honorary office arguably was more important for the Habsburgs than for the relatively unified Bourbon state, because it allowed them to strengthen the connections between the centre in Vienna and the other parts of the realm. Typically, expansion of territory went together with the introduction of honorary offices for the elites of the newly incorporated area. Maria Theresa adopted Italian and Hungarian guards and honorary officers at her court. Even Frederick II of BrandenburgPrussia, no devotee of the courtly apparatus, followed the same logic when he introduced new positions for Silesians at his court after his conquests in the wars of the Austrian succession. Arguably, the very success of Louis XIV's purge of honorary office had less positive longterm consequences. The French court in the eighteenth century had only a limited potential for accommodating relative outsiders. Offices had long since been monopolized by court families. Noble sons who had had their pedigree approved by the king's genealogist could seek to enter the stables and the chamber as pages, but numbers were limited. In addition, only the presentation to the king-with the concomitant right to join the king's procession of coaches for the hunt-was available for elites who wanted to attend court. There no longer was a close parallel for the inflated ranks of councilors and chamberlains at the Viennese court, who could legitimately see themselves as participants in the court's activities rather than as mere spectators. Everybody could visit the French court as a spectator and an outsider, but access to its formal offices and functions remained very limited.

${ }^{27}$ Mémoires de Charles-Louis Baron de Pöllnitz, 2 vols. (Amsterdam 1734) vol. 1, p. 279. 
Who would choose to remain outsider, consciously evading the court system of honour? Families priding themselves on their ancient lineage looked with dismay at the promotion of less venerable families, but in the long run usually opted for inclusion into the court's ranking. In the century of instability following the 1550's, many families changed place, and the rulers of Europe could include their trusted servants into the upper layers of a newly formed nobility, that would soon close its borders. In addition to instituting a new exclusive order of chivalry, French royalty recreated the traditional corps of ducs et pairs, in practice placing its rights of nomination and promotion above the genealogy of families. Habsburg rulers rewarded their most trusted servants with the high ranks of counts and princes-although they needed to conform to certain restrictions imposed by the collectivity of the empire, the Reichsstände. The role of the court as the centre of patronage and the adjudicator of elite ranking went together with a more general influence of the court on noble education, noble manners and style, and of course fashion. The noble extensions of the court, from pages and court ladies, knights in the orders, to honorary officers in various capacities, spread the influence of the court over larger territories. In the Habsburg case, it has been argued that the 'stamp' of the court helped to create a 'gesamthabsburgische Adel', replacing the regionally oriented noble cultures of a previous period. These noble men and women cherished their ties to the dynasty and the court, and possessed territories in the various components of Habsburg monarchy.

\section{Conclusions}

The tension between rulers and overmighty subjects recurs in history, as do the oscillations in power between the centre and regional forces. Military force would often determine the outcome of such balances, but consolidation also required less confrontational means. Courts could play a conspicuous role in stabilizing connections. The metaphor of domestication, with its connotations of herding together the elites to control them in a central palace, does not resemble common practices in early modern Europe. Not even the Sun King's admittedly successful restructuring of the court in Versailles fits the image. The household, with its remarkably flexible and variable structures, offered multiple occasions for rulers and their elites to interact. Rulers would 
'hold court' in very different settings, with a variety of groups attending. In this way, they could accommodate different territories and different elites under their courtly umbrella. If courts were able to offer an alluring meeting point for their elites, attracting them with festive occasions and with the promise of offices and honours, they could substantially alleviate the burden of governing distant provinces.

Not all groups, however, were easily charmed into loyalty and subservience. The persons closest to the ruler-notably those included in the right of dynastic succession-were also his most dangerous potential rivals. These relatives, as well as the upper layer of nobles with great regional power, needed to be held in check. We find them in the most elevated and profitable positions at the French court, clearly not isolated from power, but still in positions underlining their deference towards the ruler. The Habsburg dynasty with its world empire could accommodate its scions as viceroys and governors in many places, and dynastic demography alleviated the problem of the presence of rivals for the Viennese rulers-in fact their main concern was the production of male heirs, late under Leopold and dramatically unsuccessful under Charles VI. The more relevant Habsburg emperor's noble rivals, the other prominent dynasties of the Holy Roman Empire, ruled outside of his hereditary lands.

Charles IV had stipulated in the Golden Bull (1356) not only the rights and privileges of the electors, but also their duty to perform ritualized domestic service-on horseback-during the Frankfurt coronation banquet. Their presence could never entirely be taken for granted, but from the seventeenth century onwards the worldly electors absented themselves more often, and after the 1740 succession crisis they no longer attended in person. Ritual service could no longer be squared with their status as kings or near-sovereigns. The imperial court in this sense of the emperor being served by his electors was defunct. We see the opposite of domestication here: the rivals of the central ruler take their distance from the court, underlining their own status as rulers. The French situation shows the opposite development. The greater French nobles, drawn towards the court in a protracted process complicated by the phase of religious strife, took up their lucrative and powerful leading offices at court and turned them into major assets for their dynasties. In the case of the Holy Roman Empire, the curia maior gradually lost its allure because it could no longer attract its superior echelon of court servants. The Viennese court took over 
part of this role, but its pull was far more important in the Habsburg hereditary lands than in the Empire. In the French case, curia maior and curia minor overlapped increasingly in the immediate group of persons around the ruler. In this sense, the term domestication is justified, but it should no longer be associated with powerlessness of great nobles at court. They formed a bastion in the heart of the French state, that wouldn't budge until the 1780's.

The Habsburgs, losing their grip on the electors, were more successful than the French kings in turning their nobles into something approaching a service elite, in household as well as government. The highest Habsburg courtiers stood at a greater hierarchical distance from the ruler-the French Condé high steward, a prince du sang with a position in the line of succession, cannot be compared to the Habsburg high stewards, even if some among them, notably the Liechtenstein, finally achieved sovereign status. Moreover, no hierarchical layer stood between the highest courtiers and the royal family in France, whereas the electors and the other princes of the empire nominally still ranked between the emperor and his Viennese courtiers. This absent rival layer helped to strengthen the connections between the emperor and his Viennese courtiers. In addition to the impact of venality and heredity at the French court, these differences made Habsburg courtiers far more deferential and less contentious than their higher-ranking French colleagues.

The balance between the ruler and the upper echelon of potential rivals was a vital interest for both parties: tensions as well as rewards were far more significant here than for the second echelon of honorary noble service. Yet the honour of belonging to the court was important for this group. If nobles accepted the need of at least occasional presence at court for all persons above a certain rank, this may be the strongest argument in favour of a refurbished domestication thesis. The 'court society', then, was not so much the socially diverse group daily present and serving at court, but the wider world of noble part-time courtiers integrated into the court's 'economy of honour' through a variety of titles and offices, but not usually present at court. Integration, admittedly a term with somewhat bland and less concrete associations than domestication, approaches better the multi-layered and multi-directional character of the reorientation of nobles and rulers, and leaves room for the variations outlined here. In the Habsburg context integration of nobles was partly the unintended consequence of the proliferation of honorary titles under Leopold I. Louis XIV's 
reductions, on the other hand, in the long run may have contributed to the relative isolation of the elites assembled at court.

The integrative potential of the court was not limited to the nobility. The wider world of artisans, purveyors, labourers and specialists of many kinds likewise could be attracted into the orbit of the court, partly owing to the court's huge demand for goods and services of great variety, partly because of its ability to compensate service with exemptions and distinctions in addition to payments. Civic authorities were not pleased when court personnel used the court's legal status aparte and fiscal exemption for activities undermining the legitimate urban trades and crafts, and struggled to maintain their corporate rights against the court's repeated incursions. Yet although connections between court servants and their urban or rural environments were rarely trouble-free, they were essential for both sides. A lively amalgamation of lesser household staff with the upper layers of noble courtiers, moreover, remained typical for sixteenth- and seventeenthcentury courts, though the hierarchical separation between these levels became stronger in time. Therefore, picturing the court as an 'above stairs' world only, isolated from servants as well as from the outside world makes no sense. The Castiglionian salon with conversation among near-equal esprits fins of high rank was only one of the many manifestations of court life. 